\title{
Large scale laboratory cultures of Ankistrodesmus gracilis (Reisch) Korsikov (Chlorophyta) and Diaphanosoma biergei Korinek, 1981 (Cladocera)
}

\author{
Sipaúba-Tavares, $L H .{ }^{\mathrm{a} *}$ and Pereira, $A M L{ }^{\mathrm{b}}$ \\ a'Laboratório de Limnologia e Produção de Plâncton, Centro de Aqüicultura, \\ Universidade Estadual Paulista - UNESP, \\ Via de Acesso Prof. Paulo Donato Castellane, s/n, CEP 14884-900, Jaboticabal, SP, Brazil \\ ${ }^{\mathrm{b}}$ Empresa Brasileira de Pesquisa Agropecuária - EMBRAPA, \\ Rodovia BR 343 km, CEP 64200-970, Parnaíba, PI, Brazil \\ *e-mail: sipauba@caunesp.unesp.br \\ Received March 3, 2007 - Accepted July 23, 2007 - Distributed November 30, 2008
}

(With 2 figures)

\begin{abstract}
Large-scale lab culture of Ankistrodesmus gracilis and Diaphanososma birgei were evaluated by studying the biology and biochemical composition of the species and production costs. Ankistrodesmus gracilis presented exponential growth until the $6^{\text {th }}$ day, with approximately $144 \times 10^{4}$ cells. $\mathrm{mL}^{-1}$, followed by a sharp decrease to $90 \times 10^{4}$ cells. $\mathrm{mL}^{-1}$ $\left(8^{\text {th }}\right.$ day). Algae cells tended to increase again from the $11^{\text {th }}$ day and reached a maximum of $135 \times 10^{4}$ cells. $\mathrm{mL}^{-1} \mathrm{on}$ the $17^{\text {th }}$ day. $D$. birgei culture showed exponential growth until the $9^{\text {th }}$ day with $140 \times 10^{2}$ individuals. $L^{-1}$, and increased again as from the $12^{\text {th }}$ day. Algae A. gracilis and zooplankton D. birgei contain 47 to $70 \%$ dry weight protein and over $5 \%$ dry weight carbohydrates. The most expensive items in the context of variable costs were labor and electricity. Data suggested that temperature, nutrients, light availability and culture management were determining factors on productivity. Results indicate that NPK (20-5-20) may be used directly as a good alternative for mass cultivation when low costs are taken into account, promoting adequate growth and nutritional value for cultured A. gracilis and D. birgei.
\end{abstract}

Keywords: Ankistrodesmus gracilis, Diaphanosoma birgei, growth, biochemical composition, plankton culture.

\section{Cultivo em large escala de Ankistrodesmus gracilis (Reisch) Korsikov (Chlorophyta) and Diaphanosoma biergei Korinek, 1981 (Cladocera) em laboratório}

\begin{abstract}
Resumo
O objetivo deste trabalho foi avaliar o cultivo em larga escala de Ankistrodesmus gracilis e Diaphanososma birgei em laboratório através do estudo da biologia das espécies, composição bioquímica e custo operacional de produção. A. gracilis apresentou um crescimento exponencial até o sexto dia, ao redor de $144 \times 10^{4}$ células $\mathrm{mL}^{-1}$. Logo em seguida, sofreu um brusco decréscimo apresentando $90 \times 10^{4}$ células $\mathrm{mL}^{-1}$ (oitavo dia). A partir do décimo primeiro dia, as células algais tenderam a crescer novamente, apresentando um máximo de $135 \times 10^{4}$ células $\mathrm{mL}^{-1}$ no $17^{\circ}$ dia. No cultivo de $D$. birgei, foi observado o primeiro pico de crescimento no nono dia com $140 \times 10^{2}$ indivíduos $\mathrm{L}^{-1}$, aumentando novamente a partir do décimo segundo dia. A alga clorofícea A. gracilis e o zooplâncton D. birgei possuem aproximadamente 50 e $70 \%$ de proteína (PS), respectivamente, com teor de carboidrato acima de $5 \%$. A eletricidade e mão de obra foram os itens mais dispendiosos e, de acordo com os dados obtidos, a temperatura, nutrientes, disponibilidade de luz e manejo do cultivo, foram fatores determinantes sobre a produtividade. Os resultados indicam que o meio NPK (20-5-20) pode ser utilizado diretamente como uma alternativa de cultivo em larga escala, considerando o baixo custo de produção, promovendo adequado crescimento e valor nutricional para A. gracilis e D. birgei.
\end{abstract}

Palavras-chave: Ankistrodesmus gracilis, Diaphanosoma birgei, crescimento, composição bioquímica, cultivo de plâncton.

\section{Introduction}

Increasing demand has recently been registered to produce high quality fish for consumption on the Brazilian market and high quality nutritional food to feed fish larvae and fingerlings. However, Brazilian aquaculture lacks the technology to produce live feed of high nutritional value to increase fish survival rate, mainly during the first days of life when phytoplankton and zooplankton are the basic feed source. 
Several fish farms add chemical and organic fertilizer to their tanks to stimulate plankton development so that feed for fish larvae and fingerlings may be improved. However, the plankton nutritional quality is not greatly influenced by fertilization, but water quality determines the species composition in tanks (Santeiro et al., 2006).

One of the most important factors in successful fish rearing is probably the use of natural feed, such as phytoplankton and zooplankton, which may be grown in specially designed installations.

Fine chemical products, such as pigments, lipids, polyunsaturated fatty acids, polysaccharides, carotenoids, steroids and vitamins may be obtained from plankton (Soletto et al., 2005).

Ankistrodesmus gracilis, a species of green photoautotrophic and unicellular microalgae, may be easily cultivated in the laboratory. Diaphanosoma birgei, a species of cladocerans has been chosen because it is resistant to the handling involved in the culture system and it is selected as food by fish larvae (Sipaúba-Tavares and Bachion, 2002).

Although microalgae are the main food source for herbivorous zooplankton organisms, food quantity and quality are important factors to control zooplankton development, growth and reproduction. The need to improve the cultivation of microalgae for the nutrition of invertebrate and fish larvae has triggered many practical studies in different fields. Alternative mediums should allow efficient production of algae in the laboratory and algae should provide nutrition for several aquatic organisms.

So that high nutritional algae and zooplankton may be produced at low costs, high production and high survival rates of fish larvae are feasible. The current study aims at evaluating large-scale laboratory culture of algae Ankistrodesmus gracilis and zooplankton Diaphanosoma birgei by studying the species biology, their chemical composition and production cost by using NPK (20-5-20) as an alternative culture medium.

\section{Material and Methods}

\subsection{Algae culture}

The strain of green algae Ankistrodesmus gracilis was received from the Algae Physiology Laboratory $(005 \mathrm{CH})$, Universidade Federal de São Carlos (UFSCar), originally isolated from Broa Reservoir, São Paulo, Brazil. Algae were batch-cultured in the laboratory at $22 \pm 2{ }^{\circ} \mathrm{C}$, in a light regimen of $21.48 \mu$ Einst. $\mathrm{cm}^{-2} / \mathrm{s}$, white fluorescent light (Philips daylight tubes), on a 24 hours light cycle, and bubbled with air. Start culture was grown in $2 \mathrm{~L}$ flasks containing $\mathrm{CHU}_{12}$ medium, and then cultured in large volumes $(11,250$ and $850 \mathrm{~L})$, in NPK (20-5-20) medium, following Sipaúba-Tavares (1995). When cultures reached late exponential growth phase (day-8), their contents were transferred to sterilized glass fiber tanks containing 250 and $850 \mathrm{~L}$ of NPK-enriched fil- tered fresh water (1 and $5 \mu \mathrm{m})$. Vitamin complex B was added to the NPK medium, at a rate of $2 \mathrm{mg} . \mathrm{L}^{-1}$. Algae were grown at $24 \pm 2{ }^{\circ} \mathrm{C}$ with $78.13 \mu$ Einst. $\mathrm{cm}^{-2} / \mathrm{s}$, white fluorescent light, in 24 hours light cycles. Cultures were mixed by air bubbling, which maintained a $\mathrm{pH}$ ranging from 6.7 to 7.4 in all cultures. Three individual tanks were used during the experiment; batch-cultures were operated and maintained in the mid to late exponential phase by removing approximately 10 to $20 \%$ of the culture every 5 to 6 days and replenishing the culture with fresh medium. The pumped material (algae culture) was then fed to the culture for Diaphanosoma birgei. Mean cell size was $23.8 \times 3.3 \mu \mathrm{m}$.

\subsection{Zooplankton culture}

Diaphanosoma birgei was collected in fishponds with $58 \mu \mathrm{m}$ mesh-size plankton nets at the Aquaculture Center $\left(21^{\circ} 15^{\prime} \mathrm{S}\right.$ and $\left.48^{\circ} 18^{\prime} \mathrm{W}\right)$ of the Universidade Estadual Paulista (UNESP). Acclimation period in the laboratory lasted 2 months. Specimens were initially placed in $2 \mathrm{~L}$ flasks, then in $20 \mathrm{~L}$ glass bottles, and finally in $850 \mathrm{~L}$ tanks at $25 \pm 1{ }^{\circ} \mathrm{C}$. They were fed daily with $A$. gracilis mono algae culture during the exponential growth phase, at a density of $4 \times 10$ cells. $\mathrm{mL}^{-1}$ in $2 \mathrm{~L}$ flasks, and $25 \times 10^{4}$ cells. $\mathrm{mL}^{-1}$ in $20 \mathrm{~L}$ glass bottles and $20 \times 10^{4}$ cells. $\mathrm{mL}^{-1}$ in $850 \mathrm{~L}$ tanks. Since variation occurred in the volume of supplied algae during this period, it was adjusted as a function of algae concentration and cladoceran number.

The $850 \mathrm{~L}$ culture tanks were a bath-culture, according to Sipaúba-Tavares and Rocha (1993) and Sipaúba-Tavares et al. (1994), fed daily with A. gracilis, and pumped directly from the algae culture tank to $D$. birgei production tanks. $D$. birgei cultures started with 1,100 individual. $\mathrm{L}^{-1}$, water in the tank (corresponded to $5 \%$ of the production volume) was partially changed when the population reached density of 3,000 individual.L ${ }^{-1}$. The experiment was conducted in triplicate.

\subsection{Growth}

Duplicate $1 \mathrm{~mL}$ aliquots were removed daily form the algae culture and a minimum of $2 \times 1 \mu \mathrm{L}$ sub-sample were counted with a Neubauer hemocytometer. Growth rate was obtained using the exponential growth phase, which represented the number of cell divisions per day. Duplication time, also called division time or generation time, was calculated from results obtained from the growth rate, and may be calculated as follows:

$\mathrm{Td}=1 / \mathrm{k}$ or $\mathrm{Td}=24 / \mathrm{k}$

where: $\mathrm{Td}=$ duplication time; $1 / \mathrm{k}=$ days per division; and $24 / \mathrm{K}=$ hours per division.

Zooplankton growth was monitored daily by counting the number of organisms, using a Wild-Leitz M-5 Wild Heerburgg MDG 17 stereomicroscope. Potential growth of cladocerans was determined by the intrinsic rate of natural increase under determined laboratory conditions (Bottrell et al., 1976; Vijverberg, 1989). About 
180 organisms from each culture were measured to monitor total length.

\subsection{Production time of population (or cell time)}

Production time was considered the production cycle interval, calculated from the initial inoculation maximum volume $(850 \mathrm{~L})$.

\subsection{Biochemical composition}

Previously de-fattened algae samples were hydrolyzed by acid (Moore et al., 1958) and alkaline (Lucas and Sotelo, 1980) means to determine amino acids. Aliquots between 0.01 and $900 \mathrm{~mL}$ were inserted into the cationic exchange column of the analyzer and eluted by $\mathrm{pH}$ difference and ionic forces (Spackman et al., 1963). After chromatographic separation, amino acids eluted in the column were made to react with ninidrine at approximately $100{ }^{\circ} \mathrm{C}$, during 15 minutes. Products of this reaction were determined by a colorimeter in two wavelengths, $440 \mathrm{~nm}$ for proline and $570 \mathrm{~nm}$ for the other amino acids, respectively. Identification of amino acids was based on the detention time of each residue (Alonso and Hirs, 1968).

In the case of amino acids, zooplankton with total biomass of approximately $90 \mathrm{~g}$ produced at the end of culture, were concentrated by using a $200 \mu \mathrm{m}$ mesh-size plankton net; biomass was dried at $105^{\circ} \mathrm{C}$ and cooled in a desiccator. Analysis of protein, fat and ashes was determined following the AOAC Method (1984), while energy was calculated by a calorimetric pump PARR mod.1281. Zooplankton dry weight was determined by a Mettler high-precision balance (accuracy $\pm 0.1 \mu \mathrm{g}$ ). Cladocerans were first freeze-dried and then transferred to small preweighted aluminum "boats" following Berberovic and Pinto-Coelho (1989).

\subsection{Hydrological data}

Several hydrological variables were analyzed to evaluate the effect of water quality on the development of $D$. birgei and A. gracilis culture $(850 \mathrm{~L})$. Water samples were monitored three times a week in all tanks with a Van Dorn bottle (1 L). Dissolved oxygen was determined with an oxygen meter Orion mod. 810. The $\mathrm{pH}$, temperature and conductivity were measured with a Corning PS-17 pH meter, Corning PS-16 temperature meter and Corning PS-15 conductivity meter. Total phosphorus, orthophosphate, ammonia, nitrite and nitrate were determined according to techniques describe by Golterman et al. (1978) and Koroleff (1976).

\subsection{Economic considerations}

Production operational costs were determined according to the methodology described by Matsunaga et al., (1976). Economic aspects were analyzed taking into account $540,000 \mathrm{~L} /$ year for production of $27 \mathrm{~kg}$ of A. gracilis dry matter and $2.3 \mathrm{~kg}$ of $D$. birgei dry matter cultured in 190,000 L/year. Economical considerations did not take into account premises depreciation; however depreciation of equipment, tanks and materials was cal- culated. Costs in energy, water, nutrients, vitamins, spare parts and for a part-time technician were all calculated.

\section{Results}

\subsection{Ankistrodesmus gracilis culture}

Ankistrodesmus gracilis grew exponentially up to the $6^{\text {th }}$ day when cells totaled about $144 \times 10^{4}$ cells. $\mathrm{mL}^{-1}$; after the $6^{\text {th }}$ day, the number decreased sharply to $90 \times 10^{4}$ cells. $\mathrm{mL}^{-1}$. From the $12^{\text {th }}$ day, algae cells tended to increase again and reached a maximum of $135 \times 10^{4}$ cells.mL ${ }^{-1}$ on the $17^{\text {th }}$ day (Figure 1 ).

Constant speed for $A$. gracilis was $\mathrm{K}=0.22$, with average density of $40.75 \times 10^{4}$ cells. $\mathrm{mL}^{-1}$ during adaptation period or lag (day-1 to 3 and 8 to 10), $76 \times 10^{4}$ cells. $\mathrm{mL}^{-1}$ in the exponential phase (day-4 to 6 and 12 to 17 ) and $52 \times 10^{4}$ cells. $\mathrm{mL}^{-1}$ in the stationary phase (day-18 to 22). Production time was short, about $14.66 \pm 1.15$ days, with cell duplication around $4.54 \pm 0.41$ days (Figure 1; Table 1).

High protein values, which corresponded to almost $50 \%$ of total alga dry matter, and lipids and fiber below $8 \%$ of the dry matter, were reported. Dry weight and mineral matter rates were 10.88 pg.cell ${ }^{-1}$ and $17 \%$, respectively (Table 1).

Amino acid contents of A. gracilis were above 4\%, with the exception of methionine, isoleucine and histidin, respectively with $1.8,2.45$ and $3.0 \%$. Leucine was more abundant and corresponded to $8.7 \%$, followed by arginine, lysine, threonine, valine and tryptophan. Among the analyzed minerals, nitrogen content was the highest, with nearly $7 \%$, followed by phosphorus and calcium; zinc content was the lowest with $0.5 \%$ (Figure 2).

With the exception of nitrite, nutrients in the culture medium maintained concentrations above $100 \mu \mathrm{g} . \mathrm{L}^{-1}$.
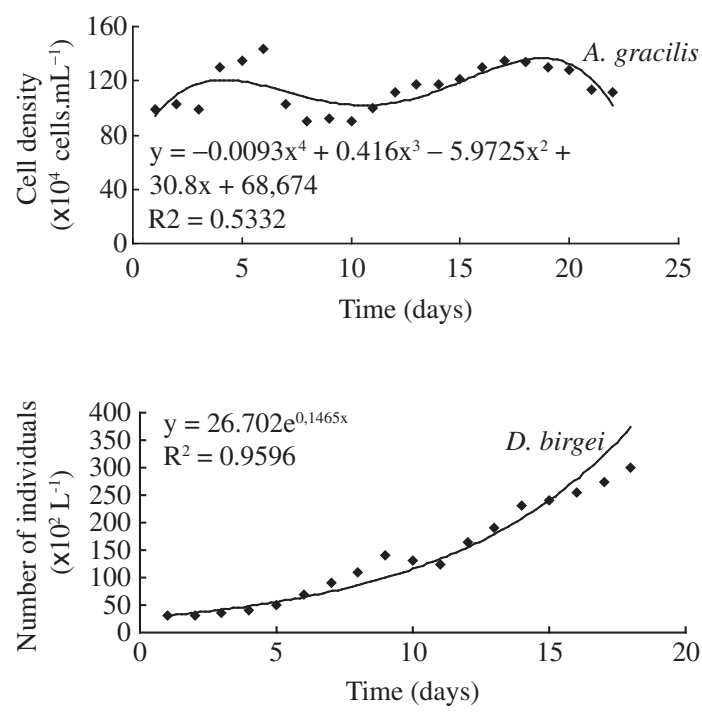

Figure 1. Ankistrodemus gracilis and Diaphanosoma birgei growth curve cultured in $850 \mathrm{~L}$ tanks. 
Among the nitrogen compounds, ammonia was dominant, with peaks around the $10^{\text {th }}$ growth day, and 1,210 $\mu \mathrm{g} . \mathrm{L}^{-1}$ concentration. Total phosphorus and orthophosphate concentrations have been generally lower than nitrogen compounds, with peaks around the $3^{\text {rd }}$ day of growth $\left(370 \mu \mathrm{g} . \mathrm{L}^{-1}\right)$ and the $10^{\text {th }}$ day of growth $\left(320 \mu \mathrm{g} . \mathrm{L}^{-1}\right)$ (Table 2).

Table 1. Life history characters and biochemical composition of Ankistrodesmus gracilis algae, cultured in $850 \mathrm{~L}$ tanks, where: DW = dry weight.

\begin{tabular}{lr}
\hline \multicolumn{1}{c}{ Characters } & \multicolumn{1}{c}{$\mathbf{8 5 0} \mathbf{L}$} \\
\hline Production cell time (days) & $14.66 \pm 1.15$ \\
Doubling times (days) & $4.54 \pm 0.41$ \\
Cell density $\left(\times 10^{4} \mathrm{~mL}^{-1}\right)$ & $6.72 \pm 2.08$ \\
Mean cell density tank $\left(\times 10^{4} \mathrm{~mL}^{-1}\right)$ & $5.93 \pm 1.65$ \\
Mean cell size $(\mu \mathrm{m})$ & $23.8 \pm 2.10$ \\
Growth rate $(\mathrm{K})$ & $0.22 \pm 0.02$ \\
Dry weight $\left(\mathrm{pg} . \mathrm{cell}{ }^{-1}\right)$ & $10.88 \pm 4.99$ \\
Dry matter $(\% \mathrm{DW})$ & $93.62 \pm 1.74$ \\
Minerals $(\% \mathrm{DW})$ & $17.10 \pm 4.86$ \\
Lipids $(\% \mathrm{DW})$ & $7.48 \pm 4.64$ \\
Fiber $(\% \mathrm{DW})$ & $3.01 \pm 3.01$ \\
Protein contents $(\% \mathrm{DW})$ & $47.31 \pm 3.03$ \\
\hline
\end{tabular}
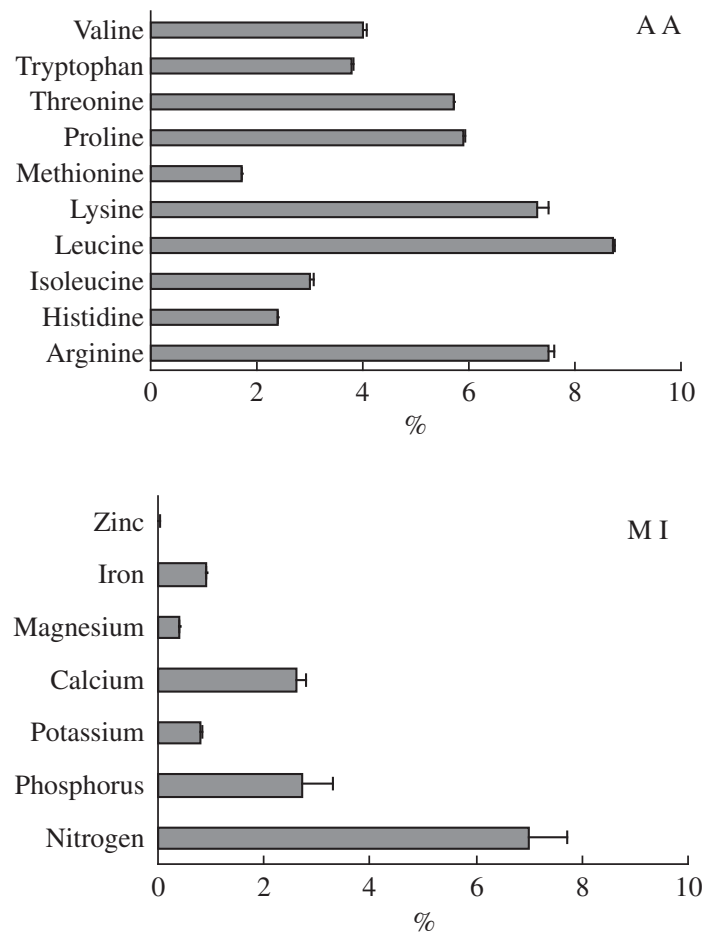

Figure 2. Ankistrodesmus gracilis essential amino acid (AA) and minerals (MI) composition (total percentage) cultured in $850 \mathrm{~L}$ tanks. The range of values is shown by range bars.

\subsection{Diaphanosoma birgei culture}

Diaphanosoma birgei showed an exponential growth until the $9^{\text {th }}$ day, with $140 \times 10^{2}$ individuals. $\mathrm{L}^{-1}$, increasing again as from the $12^{\text {th }}$ day (Figure 1 ).

The intrinsic rate of natural increase (r) was 0.18 , with reproductive rate of 4 days; primipara average size was $524 \mu \mathrm{m}$ and adults reached $952 \mu \mathrm{m}$. Production time comprised about 32 days with a density of about 2,500 individuals. $\mathrm{L}^{-1}$. Protein was higher $(70 \% \mathrm{DW})$ and lipid was lower (8.7\% DW) (Table 3).

High nitrogen and phosphorus concentrations were observed in the culture medium. Nitrate and ammonia concentrations were above $1 \mathrm{mg} . \mathrm{L}^{-1}$, directly affecting conductivity values, with approximately $90 \mu \mathrm{S} . \mathrm{cm}^{-1}$. Frequent aeration of the culture medium favored dissolved oxygen concentrations above 6 mg.L $\mathrm{L}^{-1}$ (Table 2).

\subsection{Economic considerations}

Total investment cost for a yearly production of 540,000 and 190,000 L/year of A. gracilis and D. birgei respectively, was US\$16,353 (Table 4), including US\$ 3,261 (algae + zooplankton) salary for a part-time employee for routine lab work (Tables 5 and 6).

Algae and zooplankton production running costs were 78.5 and $74.4 \%$, respectively, of total production cost. Electricity was the most expensive item, featuring above $20 \%$ of total cost, due to 24 hours light expenditure, air conditioning, centrifugations, and constant aeration of tanks (Tables 5 and 6).

Since laboratory equipment underwent several hours of intermittent work in a humid environment, wear and tear of equipment occurred and lowered the cost value in 60 and $40 \%$, respectively, for algae and zooplankton production. This fact accounted for US\$1,823 and US\$ 1,116 depreciation in the production cost of alga and zooplankton, respectively (Table 4).

Production cost of $27 \mathrm{~kg}$ in grams of DW of A. gracilis and $2.3 \mathrm{~kg}$ in grams of DW of D. birgei amounted to US\$ 0.32 and US\$ 1.9 , while the average cost per liter was US\$ 0.007 and US\$ 0.025 , respectively (Tables 5 and 6).

\section{Discussion}

The NPK (20-5-20) alternative medium associated to B complex vitamins caused growth rates that were 0.22 slower than those reported by Foy and Gibson (1993) for marine diatoms cultured in a commercial medium.

A. gracilis culture in $850 \mathrm{~L}$ tanks promoted a density above $80 \times 10^{4}$ cells. $\mathrm{mL}^{-1}$ during the exponential growth phase. This is enough for larviculture since the number of algae cells recommended by Smandych and Hiemstra (2001) at the beginning of larval development is about 6,000 cells. $\mathrm{mL}^{-1} /$ day.

Toro (1989) found that phytoplankton growth is not a function of photoperiod but of total amount of light per day. High algae density was high in this study and may be associated to 24 hours light. 
According to Meseck et al. (2005), the division rate of algae has a minimal photoperiod requirement for maximal growth. However, once the minimum photoperiod is met, growth rate is a function of the total daily light input. The maintenance of the culture in the laboratory with regard to luminosity, temperature and aeration is fundamental for the development and exponential growth of algae (Sipaúba-Tavares et al., 1999).

$D$. birgei had a daily photoperiod with an intensity of approximately $60 \mu$ Einst. $\mathrm{cm}^{-2} / \mathrm{s}$ during the light period. This is due to the fact that these organisms require around $58.6 \mu$ Einst. $\mathrm{cm}^{-2} / \mathrm{s}$ for proper growth (Fermin and Seronay, 1997).

The nutrition value of feed affects the zooplankton population's growth rate and influences the fingerlings' development period, reproduction rate and reproduction frequency (Prieto et al., 2006). The above has been corroborated in current work when high density of over $70 \times 10^{2}$ individuals. $\mathrm{L}^{-1}$ for $D$. birgei fed on A. gracilis was found.

In the current study, A. gracilis presented methionine and histidine rates above $3.2 \% \mathrm{DW}$, while in general, amino acids varied between 0.6 to $9.0 \%$ DW. Although differences in the species composition may be attributed to genetics, differences are frequently due to the culture conditions and laboratory methodology.

In the case of $850 \mathrm{~L}$ cultures, protein content of A. gracilis and D. birgei amounted to about 47 and $70 \%$ DW, respectively, with $5 \%$ DW of carbohydrate. In their work on D. birgei fed on A. gracilis and cultured in a NPK medium (1.8 L), Sipaúba-Tavares and Bachion (2002) reported a protein level of $70 \%$ DW and carbohydrate $15 \% \mathrm{DW}$ at $26{ }^{\circ} \mathrm{C}$. It may be concluded that the volume affects the algae quality.

According to Brown et al. (1997), different growth stages influence the quantity and quality of the protein and carbohydrates. The above authors remarked that during the stationary phase culture Isochrysis sp. contained approximately two to four times more carbohydrates and 30 to $50 \%$ less protein than during the logarithmic phase.

Minerals such as iron, zinc and magnesium enhance natural productivity of cultured algae (Saadoun et al., 2001). In this study, the contents of these elements in the culture medium were low and ranged between 0.2 and
$0.9 \%$. Changes in culture conditions, even small ones, may cause morphological and/or physiological differences in the biochemical properties of the cultured algae (Leonardos and Lukas, 2000).

Algae-fed zooplankton biomass has a strong correlation with the nutrition value of the feed which will affect the cultivated organism's performance and size (Prieto et al., 2006). Size of algae in the current study was similar to that reported by Sipaúba-Tavares and Rocha (1993) and lower than that by Hardy and Castro (2000); average $D$. birge $i$ size of primipara and adult was similar to that obtained by Castro and Hardy (1998).

Temperature is a factor that affects the size of zooplankton populations cultivated in lab conditions. Temperature rates in the current study corroborate those in indoor tanks found by Sipaúba-Tavares et al., (1994, 1999) and by Hardy and Castro (2000).

As a rule, survival of cladocerans is related to temperature since the intrinsic rate of natural (r) and reproduction rates increases in direct proportion to tempera-

Table 3. Life history characters and biochemical composition of cladoceran Diaphanosoma birgei fed with algae Ankistrodesmus gracilis, in $850 \mathrm{~L}$ tanks in the laboratory, where: DW = dry weight.

\begin{tabular}{lc}
\hline \multicolumn{1}{c}{ Characters } & $\begin{array}{c}\text { Diaphanosoma } \\
\text { birgei }\end{array}$ \\
\hline Intrinsic rate of natural increase $(\mathrm{r})$ & $0.18 \pm 0.07$ \\
Mean primipara size $(\mu \mathrm{m})$ & $524.40 \pm 98.25$ \\
Mean adult size $(\mu \mathrm{m})$ & $952.00 \pm 224.02$ \\
Maximum adult size $(\mu \mathrm{m})$ & $1,594(168)$ \\
Production of population & $27.45 \pm 4.55$ \\
time (days) & \\
Maximum density & $28.13 \pm 3.65$ \\
(individual x $\left.10^{2} \mathrm{~L}^{-1}\right)$ & $70 \pm 7.8$ \\
Protein contents $(\% \mathrm{DW})$ & $8.71 \pm 0.9$ \\
Lipid $(\% \mathrm{DW})$ & $5.47 \pm 0.44$ \\
Carbohydrate $(\% \mathrm{DW})$ & $4.28 \pm 0.5$ \\
Fiber $(\% \mathrm{DW})$ & $11.54 \pm 0.8$ \\
Ash contents $(\% \mathrm{DW})$ & $4.8 \pm 2.27$ \\
Dry weight $\left(\mathrm{pg} . \mathrm{L}^{-1}\right)$ & \\
\hline
\end{tabular}

Table 2. Mean variation of hydrological characteristics of Ankistrodesmus gracilis and Diaphanosoma birgei in the culture water, during the experimental period in $850 \mathrm{~L}$ tanks.

\begin{tabular}{lcc}
\hline \multicolumn{1}{c}{ Hydrological characteristics } & Ankistrodesmus gracilis & Diaphanosoma birgei \\
\hline Dissolved oxygen $\left(\mathrm{mg} . \mathrm{L}^{-1}\right)$ & $6.68 \pm 0.67$ & $6.85 \pm 1.35$ \\
Electrical conductivity $\left(\mu \mathrm{S} . \mathrm{cm}^{-1}\right)$ & $190.0 \pm 37.5$ & $90.25 \pm 64.0$ \\
Nitrite $\left(\mu \mathrm{g} . \mathrm{L}^{-1}\right)$ & $8.78 \pm 9.84$ & $403.72 \pm 65.18$ \\
Nitrate $\left(\mu \mathrm{g} . \mathrm{L}^{-1}\right)$ & $190.57 \pm 87.88$ & $1,681.45 \pm 234.10$ \\
Ammonia $\left(\mu \mathrm{g} . \mathrm{L}^{-1}\right)$ & $1,069.97 \pm 152.39$ & $1,023.4 \pm 62.75$ \\
Total phosphorus $\left(\mu \mathrm{g} . \mathrm{L}^{-1}\right)$ & $375.55 \pm 14.75$ & $757.1 \pm 23.7$ \\
Orthophosphate $\left(\mu \mathrm{g} . \mathrm{L}^{-1}\right)$ & $321.45 \pm 12.17$ & $381.45 \pm 12.17$ \\
\hline
\end{tabular}


Table 4. Investment costs in US $\$$ a dollar (excluding infrastructure) for tanks of $850 \mathrm{~L}$ producing of 540,000 L/year, of Ankistrodesmus gracilis and 190,000 L/year Diaphanosoma birgei.

\begin{tabular}{lccccc}
\hline \multicolumn{1}{c}{ Laboratory components } & Cost & $\begin{array}{c}\text { Lifespan } \\
\text { (years) }\end{array}$ & $\begin{array}{c}\text { Depreciation } \\
\text { per year }\end{array}$ & $\begin{array}{c}\text { Depreciation of } \\
\text { algae (60\%) }\end{array}$ & $\begin{array}{c}\text { Depreciation of } \\
\text { zooplankton (40\%) }\end{array}$ \\
\hline Two water pumps (1/4 HP) & 497 & 8 & 62 & 37 & 25 \\
Two air pumps (1/4 HP) & 1,862 & 8 & 233 & 140 & 93 \\
Fifteen glass fiber tanks (850 1) & 3,508 & 10 & 351 & $351 *$ & $351 *$ \\
Microscopic Olympus SZ 40 & 5,456 & 5 & 1,091 & 655 & 436 \\
Two air-conditioners (1 HP) & 1,862 & 5 & 372 & $223 *$ & $149 *$ \\
Balance & 1,544 & 10 & 154 & $92 *$ & $62 *$ \\
Centrifuge algae & 1,355 & 5 & 271 & 271 & - \\
Three Neubauer chambers & 269 & 5 & 54 & 54 & 1,116 \\
Total investment cost & 16,353 & - & 2,457 & 1,823 & - \\
\hline
\end{tabular}

${ }^{a}$ Average exchange rate (August 2003) US\$ $1.00=\mathrm{R} \$ 2.98$; and *limited use (100\% of depreciation of each culture).

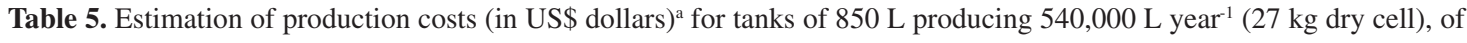
Ankistrodesmus gracilis.

\begin{tabular}{|c|c|c|c|}
\hline Production input & Assumptions & Cost (US\$) & $\begin{array}{l}\text { Percent } \\
\text { of total }\end{array}$ \\
\hline (1) Labor & Cost of labor (2 to 4 hours) & - & - \\
\hline $\begin{array}{l}\text { a) Preparing of nutrient medium, harvesting, } \\
\text { cleaning of algae tanks, simple technical main- } \\
\text { tenance, } 1 \text { hour/day }(365)\end{array}$ & - & - & - \\
\hline $\begin{array}{l}\text { b) Laboratory work } 1 / 2 \text { hour/day, counting and } \\
\text { checking cells under microscope }(182.5)\end{array}$ & - & - & - \\
\hline $\begin{array}{l}\text { c) Basic technical and replacing parts i.e. fix- } \\
\text { ing and replacing parts } 1 / 2 \text { hour/day (182.5) }\end{array}$ & - & - & - \\
\hline Total labor 730 hour/year & - & $1,445-2,915$ & \\
\hline Average & - & 2,185 & 25.7 \\
\hline (2) Energy in Kw hour/year & Cost of electricity US $\$ 0.10 \mathrm{~kW} / \mathrm{h}$ & & \\
\hline Air pump $(1,577)$ & $0.18 \mathrm{~kW} \times 24$ hours/day x 365 days/year & 159 & 1.9 \\
\hline Culture room lamps $(3,504)$ & $0.40 \mathrm{~kW} \times 24$ hours/day $\times 365$ days/year & 353 & 4.2 \\
\hline Culture room lamps (964) & $0.11 \mathrm{~kW} \times 24$ hours/day $\times 365$ day/year & 97 & 1.1 \\
\hline Water pump $(6,132)$ & $0.70 \mathrm{~kW} \times 24$ hours/day $\times 365$ day/year & 617 & 7.3 \\
\hline Air-conditioner $(12,264)$ & $1.40 \mathrm{~kW} \times 24$ hours/day $\times 365$ days/year & 1,235 & 14.5 \\
\hline Centrifuge algae $(3,833)$ & $0.70 \mathrm{kw}$ x 15 hours/day x 365 days/year & 386 & 4.5 \\
\hline $\begin{array}{l}\text { (3) Nutrients NPK (20-5-20) use to } \\
\text { 1.3 L.tank }{ }^{-1}\end{array}$ & 217 one ton & 17 & 0.2 \\
\hline (4) Vitamins & 1,71 per glass with 30 capsules & 318 & 3.8 \\
\hline (5) Maintenance and miscellaneous & & 1,175 & 13.8 \\
\hline (6) Water (730 m³/year) & Cost of water $0.18 \mathrm{~m}^{-3}$ & 132 & 1.5 \\
\hline Running cost & - & $6,674^{\mathrm{b}}$ & 78.5 \\
\hline Depreciation per year & - & 1,826 & 21.5 \\
\hline Total annual costs & - & $8,500^{\mathrm{b}}$ & 100.0 \\
\hline Cost of gram dry cell mass & - & 0.32 & - \\
\hline Cost of liter ${ }^{\mathrm{c}}$ & - & 0.014 to 0.017 & - \\
\hline Average & - & 0.015 & - \\
\hline
\end{tabular}

${ }^{a}$ Average exchange rate (August 2003) US\$ $1.00=\mathrm{R} \$ ; 2.98$; ${ }^{\mathrm{b}}$ Average cost considering low and high labor costs; and ${ }^{\mathrm{c}}$ Cost (US\$) for liter: (total running cost + total investment per year), assuming production of 540,000 L/year $=(5,994$ $+1,826) / 540,000 \mathrm{~L}$ to $(7,404+1,826) / 540,000 \mathrm{~L}=0.014$ to 0.017 . 
Table 6. Estimation of production costs (US\$ dollars) a for tanks of $850 \mathrm{~L}$ producing $190,000 \mathrm{~L} \mathrm{year}^{-1}(2.3 \mathrm{~kg}$ dry matter), of Diaphanosoma birgei.

\begin{tabular}{|c|c|c|c|}
\hline Production input & Assumptions & Cost (US\$) & $\begin{array}{c}\text { Percent } \\
\text { of total }\end{array}$ \\
\hline (1) Labor & Cost of labor (2 to 4 hours) & & \\
\hline $\begin{array}{l}\text { a) Zooplankton aclimatation, } 1 / 2 \text { hour/day } \\
\text { (182.5) }\end{array}$ & - & - & - \\
\hline $\begin{array}{l}\text { b) Laboratory work } 1 / 2 \text { hour/day, counting and } \\
\text { checking cells under microscope }(182.5)\end{array}$ & - & - & - \\
\hline $\begin{array}{l}\text { c) Basic technical and replacing parts i.e. fixing } \\
\text { and replacing parts } 1 / 2 \text { hour/day }(182.5)\end{array}$ & - & - & - \\
\hline Total labor 360 hours/year & - & $717-1,438$ & - \\
\hline Average & - & 1,076 & 24.7 \\
\hline (2) Energy in Kw hour/year & Cost of electricity US\$ $0.10 \mathrm{~kW} / \mathrm{h}$ & - & - \\
\hline Air pump $(1,037)$ & $0.18 \mathrm{~kW} \times 24$ hours/day $\times 240$ days/year & 104 & 2.4 \\
\hline Water pump $(4,032)$ & $0.70 \mathrm{~kW} \times 24$ hours/day $\times 240$ days/year & 406 & 9.3 \\
\hline Air-conditioner $(8,064)$ & $1.40 \mathrm{~kW} \times 24$ hours/day $\times 240$ days/year & 812 & 18.6 \\
\hline (3) Nutrients algae & $97,7501 /$ year of algal & 3 & 0.07 \\
\hline (4) Vitamins & 1.71 per glass with 30 capsules & 318 & 7.3 \\
\hline (5) Maintenance and miscellaneous & - & 486 & 1.2 \\
\hline (6) Water (190 m³/year) & Cost of water $0.18 \mathrm{~m}^{-3}$ & 35 & 0.8 \\
\hline Running cost & - & $3,240^{\mathrm{b}}$ & 74.4 \\
\hline Depreciation per year & - & 1,116 & 25.6 \\
\hline Total annual costs & - & $4,356^{\mathrm{b}}$ & 100.0 \\
\hline Cost of gram dry cell mass & - & 1.90 & - \\
\hline Cost of liter & - & 0.02 to $0.03^{\mathrm{c}}$ & - \\
\hline Average & - & 0.025 & - \\
\hline
\end{tabular}

${ }^{a}$ Average exchange rate (August 2003) US\$ $1.00=\mathrm{R} \$ 2.98 ;{ }^{\mathrm{b}}$ Average cost considering low and high labor costs; and ${ }^{\mathrm{c}} 190,000 \mathrm{~L} /$ year $=(2,881+1,116) / 190,000 \mathrm{~L}$ to $(3,602+1,116) / 190,000 \mathrm{~L}=0.02$ to 0.03 .

ture rise and, consequently, a decrease in generation time (Lemke and Benke, 2003).

Although D. birgei's r (0.18) was lower than that obtained by Sipaúba-Tavares and Bachion (2002) for the same species in a $2 \mathrm{~L}$ culture medium, maximum density $\left(2,813\right.$ individuals. $\left.\mathrm{L}^{-1}\right)$ was higher than that obtained by Prieto et al. (2006) with Moina sp. fed on Ankistrodesmus sp. in $20 \mathrm{~L}\left(1,230\right.$ individuals. $\left.\mathrm{L}^{-1}\right)$.

Excess of ammonia ( $\left.>1 \mathrm{mg} . \mathrm{L}^{-1}\right)$ in culture medium may have affected the density and the performance of A. gracilis and D. birgei in the cultivated medium. As a rule, ammonia accumulation usually inhibits biomass growth and in fact prevents appropriate pulse-feeding patterns (Soletto et al., 2005). In this study the concentration of nitrogen compound, associated to nitrogen ratio, is contained in the NPK culture medium.

Data suggested that temperature, nutrients, light availability and culture management are determining factors on productivity. Natural diets are nutritionally better than artificial ones and contain certain amino acids or minerals that are vital to development and growth of fish larvae and fingerlings.

In the context of variable costs, the most expensive items were labor and electricity, representing more than
$34 \%$ of total annual production cost. The latter may be decreased by photocells with natural photoperiod or by an assessment on whether a lower light intensity may be used without jeopardizing the production of A. gracilis.

In their research on Thalassiossira pseudomona, Brown et al. (1997) verified that the best nutritional yields occurred under continuous light (50 to $100 \mu$ Einst. $\mathrm{m}^{-2} / \mathrm{s}$ ) when compared to alternating controlled exposure of 12 hours light/12 hours dark (100 $\mu$ Einst. $\left.\mathrm{m}^{-2} / \mathrm{s}\right)$. Research on the ideal use of light will reveal satisfactory results on cost reduction.

Mean total production costs per liter of algae amounted to US\$ 0.007 , less than US\$ $4.00 \mathrm{~L}^{-1}$ obtained by Cheng-Wu et al. (2001) for the production of Nannochloropsis sp. Large scale culture of natural feed is still limited by methodology and economic factors. According to Langdon and Önal (1999), production costs of algae are high and amount to about $30 \%$ of total production of bivalve seeding Mytilus gallaprovincialis.

Microalgae mass culture is currently a viable commercial source comprising high biomass and nutrition rates, albeit production success is still debated. Further studies are needed for the development of a mass culture technology of algae and zooplankton available in the 
least culture time possible with the best use of resources. Algae Chlorophyceae A. gracilis and Cladocera D. birgei adapted themselves to large scale culture conditions with fast growth and high nutrition rate, as well as to the management involved in this production system. Results indicate that NPK (20-5-20) may be used directly as a good alternative for mass cultivation due to low cost and for its good results in the growth and nutritional value of A. gracilis and $D$. birgei.

Acknowledgements - We would like to thank Maria I. E. G. Martins for providing the economic considerations. Thanks are due to the State of São Paulo Foundation for Research Support (Fundação de Amparo à Pesquisa do Estado de São Paulo FAPESP) for financial support and for the scholarship to A. M. L. Pereira.

\section{References}

ALONSO, N. and HIRS, CHW., 1968. Automation of sample application in amino acid analyzers. Anal. Biochem, vol. 23, no. 3 , p. 272-278.

A.O.A.C. - Association of Official Agriculture Chemists, 1984. Official methods of analysis of the association of agriculture chemists. Arlington. 123 p.

BERBEROVIC, R. and PINTO-COELHO, RM., 1989. Dry first, measure later: a new procedure to preserve and measure zooplankton for eco-physiological studies. J. Plankton Res., vol. 11, no. 5, p. 1109-1116.

BOTTRELL, HH., DUNCAN, A., GLIWICZ, ZM., GRYGIEREK, E., HERZIG A., HILLBRICHT-ILKOWSKA, A., KURASAWA, H., LARSSON, P. and WEGLENSKA, T., 1976. A review of some problems in zooplankton production studies. Norw. J. Zool, vol. 24, no. 2, p. 419-456.

BROWN, MR., JEFFREY, SW., VOLKMAN, JK. and DUNSTAN, GA., 1997. Nutritional properties of microalgae for mariculture. Aquaculture, vol. 151, no. 1-4, p. 315-331.

CASTRO, JGD. and HARDY, ER., 1998. Life history of Moina micrura (KURZ) fed with three algae species, in the laboratory. Amazoniana, vol. 15, no. 1, p. 25-34.

CHENG-WU, Z., ZMORA, O., KOPEL, R. and RICHMOND, A., 2001. An industrial-size flat plate glass reactor for mass production of Nannochloropsis sp (Eustigmatophyceae). Aquaculture, vol. 195, no. 1-2, p. 35-49.

FERMIN, A. and SERONAY, G., 1997. Effects of different illumination levels on zooplankton abundance, feeding periodicity, growth and survival of the Asian sea bass, Lates calcarifer (Bloch), and fry in illuminated floating nursery cages. Aquaculture, vol. 157, no. 3-4, p. 227-237.

FOY, RH. and GIBSON, CE., 1993. The influence of irradiance, photoperiod and temperature on growth kinetics of three planktonic diatoms. Eur.J.Phycol, vol. 28, no. 4, p. 203-212.

GOLTERMAN, HL., CLYMO, RS. and OHNSTAD, MAM., 1978. Methods for physical \& chemical analysis of fresh water. London: Blackwell Scientific Publications. 213 p.

HARDY, ER. and CASTRO, JGD., 2000. Qualidade nutricional de três espécies de clorofíceas cultivadas em laboratório. Acta Amazônica, vol. 30, no. 1, p. 39-47.
KOROLEFF, F., 1976. Determination of nutrients. In: E. Grashof and E. Kremling (Eds.). Methods of sea water analysis. New York: Verlag Chemie Wenhein. p. 117-181.

LANGDON, C. and ÖNAL, E., 1999. Replacement of living microalgae with spray-dried for the marine mussel Mytilus galloprovincialis. Aquaculture, vol. 180, no. 3-4, p. 283-294.

LEMKE, A. and BENKE, A., 2003. Growth and reproduction of three cladoceran species from a small wetland in the southeastern U.S.A. Freshwater Biology, vol. 48, no. 4, p. 589-603.

LEONARDOS, N. and LUKAS, IAN., 2000. The nutritional value of algae grown under different culture conditions for Mytilus edulis L. larvae. Aquaculture, vol. 182, no. 3-4, p. 301-315

LUCAS, B. and SOTELO, A., 1980. Effect of different alkalies, temperatures and hydrolises times on tryptophan determination of pure proteins and food. Anal. Bioche, vol. 109, no. 1, p. 192-197.

MATSUNAGA, M., BEMELMANS, PF., TOLEDO, PEN., DULLEY, RD., OKAWA, H. and PEDROSO, IA., 1976. Metodologia do custo de produção utilizada pelo IEA. Agricultura em São Paulo, vol. 23, no. 1, p. 123-139.

MESECK, SL., ALIX, JH. and WIKFORS,GH., 2005. Photoperiod and light intensity effects on growth and utilization of nutrients by the aquaculture feed microalga, Tetraselmis chui (PLY 429). Aquaculture, vol. 246, no. 1-4, p. 393-404.

MOORE, S., SPACKMAN, DH. and STEIN, WH., 1958. Chromatography of amino acid on sulfonated polystyrene resins. Anal.Chem., vol. 30, no. 7, p. 1185-1190.

PRIETO, M., De La CRUZ, L. and MORALES, M., 2006. Cultivo experimental del cladocero Moina sp alimentado com Ankistrodesmus sp y Saccharomyces cereviseae. Ver. MVZ Córdoba, vol. 11, no. 1, p. 705-7414

SAADOUN, IMK., SCHRADER, KK. and BLEVINS, WT., 2001. Environmental and nutritional factors affecting geosmin synthesis by Anabaena sp. Water Research, vol. 35, no. 5, p. $1209-1218$.

SANTEIRO, RM., PINTO-COELHO, RM. and SIPAÚBATAVARES, LH., 2006. Diurnal variation of zooplankton biochemical composition and biomass in plankton production tanks. Acta Sci. Biol. Sci., vol. 28, no. 2, p. 103-108.

SIPAÚBA-TAVARES, LH., 1995. Limnologia Aplicada à Aqüicultura. São Paulo: FUNEP/UNESP Ed. 72 p. (Boletim Técnico ${ }^{\circ} 1$ ).

SIPAÚBA-TAVARES, LH. and ROCHA, O., 1993. Cultivo em larga escala de organismos planctônicos para alimentação de larvas e alevinos de peixes: I - Algas Clorofíceas. Biotemas, vol. 6 , no. 1 , p. 93-106.

SIPAÚBA-TAVARES, LH., BACHION, MA. and ROCHA, O., 1994. Estudo do crescimento populacional de três espécies zooplanctônicas em laboratório e o uso do plâncton na alimentação de alevinos de Oreochromis niloticus (tilápia) e Astyanax scabripinis paranae (lambari). Revista Unimar, vol. 16, no. 3, p. 189-201.

SIPAÚBA-TAVARES, LH., PELICIONE, LC. and OLIVERA, A., 1999. Use of organic (NPK) and the $\mathrm{CHU}_{12}$ medium for cultivation of Ankistrodesmus gracilis in laboratory. Braz. J. Biol. $=$ Rev. Bras. Biol., vol. 1, p. 10-15. 
SIPAÚBA-TAVARES, LH. and BACHION, MA., 2002. Population growth and development of two species of Cladocera, Moina micrura and Diaphanosoma birgei, in laboratory. Braz. J. Biol. $=$ Rev. Bras. Biol, vol. 62, p. 701-711.

SMANDYCH, CE. and HIEMSTRA, LD., 2001. Results of a comparative cost analysis between carboy and bag phytoplankton culture methods. Aquacul. Assoc. Canada Spec. Publ, vol. 4, no. 4, p. 107-109.

SOLETTO, D., BINAGHI, L., LODI, A., CARVALHO, JCM. and CONVERTI, A., 2005. Batch and fed-batch cultivations of Spirulina platensis using ammonium sulphate and urea as nitrogen sources. Aquaculture, vol. 243, no. 1-4, p. 217-224.

SPACKMAN, DH., STEIN, WH. and MOORE, S., 1963. Automatic recording apparatus for use in the chromatography of amino acids. Anal. Chem., vol. 30, no. 7, p. 1190-1206.

TORO, JE., 1989. The growth rate of two species of microalgae used in shellfish hatcheries cultured under two light regimes. Aquac. Fish. Manage., vol. 20, no. 3, p. 249-254.

VIJVERBERG, J., 1989. Culture techniques for studies on the growth, development and reproduction of copepods and cladocerans under laboratory and in situ conditions: a review. Freshwat. Biol., vol. 21, no. 3, p. 317-373. 